\title{
Identification of the Midgut Microbiota of An. stephensi and $A$ n. maculipennis for Their Application as a Paratransgenic Tool against Malaria
}

\author{
Navid Dinparast Djadid ${ }^{1 *}$, Hoda Jazayeri ${ }^{1}$, Abbasali Raz ${ }^{1}$, Guido Favia ${ }^{2}$, Ignacio Ricci ${ }^{2}$, Sedigheh Zakeri ${ }^{1}$
}

1 Malaria and Vector Research Group (MVRG), Biotechnology Research Center (BRC), Pasteur Institute of Iran, Tehran, Iran, 2 School of Biosciences \& Biotechnology, University of Camerino, Camerino, Italy

\begin{abstract}
The midgut microbiota associated with Anopheles stephensi and Anopheles maculipennis (Diptera: Culicidae) was investigated for development of a paratransgenesis-based approach to control malaria transmission in Eastern Mediterranean Region (EMR). Here, we present the results of a polymerase chain reaction (PCR) and biochemical-based approaches to identify the female adult and larvae mosquitoe microbiota of these two major malaria vectors, originated from South Eastern and North of Iran. Plating the mosquito midgut contents from lab-reared and field-collected Anopheles spp. was used for microbiota isolation. The Gram-negative and Gram-positive bacterial colonies were identified by Gram staining and specific mediums. Selected colonies were identified by differential biochemical tests and 16S rRNA gene sequence analysis. A number of 10 An. stephensi and 32 An. maculipennis adult mosquitoes and 15 An. stephensi and 7 An. maculipennis larvae were analyzed and 13 sequences of 16S rRNA gene bacterial species were retrieved, that were categorized in 3 classes and 8 families. The majority of the identified bacteria were belonged to the $\gamma$-proteobacteria class, including Pseudomonas sp. and Aeromonas sp. and the others were some closely related to those found in other vector mosquitoes, including Pantoea, Acinetobacter, Brevundimonas, Bacillus, Sphingomonas, Lysinibacillus and Rahnella. The 16S rRNA sequences in the current study aligned with the reference strains available in GenBank were used for construction of the phylogenetic tree that revealed the relatedness among the bacteria identified. The presented data strongly encourage further investigations, to verify the potential role of the detected bacteria for the malaria control in Iran and neighboring countries.
\end{abstract}

Citation: Dinparast Djadid N, Jazayeri H, Raz A, Favia G, Ricci I, et al. (2011) Identification of the Midgut Microbiota of An. stephensi and An. maculipennis for Their Application as a Paratransgenic Tool against Malaria. PLoS ONE 6(12): e28484. doi:10.1371/journal.pone.0028484

Editor: François Leulier, French National Centre for Scientific Research - Université Aix-Marseille, France

Received April 30, 2011; Accepted November 9, 2011; Published December 6, 2011

Copyright: ( 2011 Dinparast Djadid et al. This is an open-access article distributed under the terms of the Creative Commons Attribution License, which permits unrestricted use, distribution, and reproduction in any medium, provided the original author and source are credited.

Funding: This work has been jointly funded by Deputy for Research, MOH, I.R. Iran and Pasteur Institute of Iran in the frame of "International Research Cooperation and Grant Scheme" dme.behdasht.gov.ir; www.pasteur.ac.ir. The funders had no role in study design, data collection and analysis, decision to publish, or preparation of the manuscript.

Competing Interests: The authors have declared that no competing interests exist.

*E-mail: navidmvrg@gmail.com

\section{Introduction}

Malaria, tuberculosis and AIDS are the most important infectious diseases in the world, while malaria has been considered as the major parasitic and vector-borne disease in Iran and also the main health problem in South-Eastern parts of the country. Across the Kerman, Hormozgan and Sistan and Baluchestan provinces, around 10,000 cases of malaria infections have been reported in 2008 and 4.1 million people are considered to be at risk of infection (Centers for Disease Control and prevention (CDC), Iran, unpublished data).

Since the discovery that mosquitoes are the vectors of malaria parasite by Ronald Ross [1,2], vector control has become an important part of malaria control programs. Several strategies have been designed and put into place to reduce the mosquito population, and several others are currently being investigated as possible solutions for rendering the mosquito vector less competent to transmit malaria. These strategies include environmental management, insecticide treatments and molecular entomology approaches [3]. One of the newly developed approaches that has been proposed as an anti-Plasmodium effector delivery strategy is paratransgenesis, which is the genetic modification of symbiotic microorganisms to deliver anti-pathogenic products and thus reduce vector competence[4].

Paratransgenesis studies were started by Durvasula et al. [5] to break the transmission of American trypanosomiasis (Trypanosoma cruzi) by Rhodnius prolixus, which, in turn, fostered attempts for controlling other diseases like malaria. In early 1960s, a few studies were carried out on midgut microbiota of laboratory-bred species of Culex $[6,7,8]$. Further, the presence of oxidase-positive bacteria from the midgut of anopheline mosquitoes [9] and also, the successful colonization of Serratia marcescens in laboratory-bred $A n$. stephensi were reported [10]. A study of wild Aedes triseriatus, Cx. pipiens, and Psorophora columbiae using routine laboratory bacteriologic techniques indicated the presence of S. marcescens, Klebsiella ozonae, Pseudomonas aeruginosa, and Enterobacter agglomerans [11]. Moreover, the examination of the $C x$. quinquefasciatus larvae midgut indicated the presence of bacteria represented by Bacillus spp., Staphylococcus spp. and Pseudomonas spp., while Aspergillus and Streptomyces spp. represented the fungal and actinomycete inhabitants, respectively. Chao and Wistreich [7], Vasanthi and Hoti [12], Jadin et al. [9] found Pseudomonas sp. in the midgut of mosquitoes from the Democratic Republic of the Congo. Straif 
et al. [13] identified 20 different genera of midgut bacteria from $A n$. gambiae sensu lato and An. funestus mosquitoes caught in Kenya and Mali. They identified Pantoea agglomerans (synonym Enterobacter agglomerans) as the most frequently isolated bacterium, apart from Escherichia coli. Gonzalez-Ceron et al. [14] isolated Enterobacter amnigenus, Enterobacter cloacae, Enterobacter sp., Serratia marcescens, and Serratia sp. from An. albimanus mosquitoes caught in southern Mexico.

Pidiyar et al. [15] reported the isolation and taxonomic characterization of some species, Aeromonas culicicola, from the midgut of $C x$. quinquefasciatus and two strains of $A$. culicicola from Aedes aegypti, indicating that different mosquito species in the same environment may harbor common representatives of the microbiota. Pidiyar et al. [16] studied the midgut microbiota of wild $C x$. quinquefasciatus and Lindh et al. [17] reported 16 bacteria species from 14 genera in An. gambiae sensu lato and An. funestus.

In this report, we studied the midgut microbiota of Iranian $A n$. stephensi and An. maculipennis mosquitoes by using biochemical identification and molecular techniques with the aim to identify suitable candidates to develop an effective strategy for malaria control in Iran and perhaps Eastern Mediterranean region.

\section{Results and Discussion}

Here, we have presented the results of culture-dependent biochemical tests and polymerase chain reaction (PCR)-based approach to identify midgut bacteria associated with An. stephensi and An. maculipennis, two major malaria vectors in Iran.

Plating the mosquito midgut contents from lab-reared and fieldcollected An. stephensi and An. maculipennis (Female adult/larvae) and also the water of their breeding sites was used for isolation of culturable microflora. At first, prepared samples were cultured on blood Agar medium and next, different morphological colonies (based on the colony size, shape, color and margin) were cultured on Blood Agar (for isolation of Gram-positive bacteria) and MacCONKEY media (for isolation of Gram-negative bacteria) in parallel.

The Gram-negative bacteria colonies were identified by culturedependent biochemical tests such as IMViC, oxidase and etc. Also, the Gram-positive bacteria colonies were studied by Gram staining (for morphology characteristics) and supplemental tests such as Bacitracine sensitivity, catalase, coagulase, Novobiocine sensitivity, Optochine and etc. They were further selected on the basis of colony characteristics too. The selected colonies were identified by the analysis of the 16S rRNA gene sequence.

From 10 An.stephensi and 32 An. maculipennis adult mosquitoes and $15 \mathrm{An}$. stephensi and $7 \mathrm{An}$. maculipennis larvae analyzed, we retrieved 13 sequences of $16 \mathrm{~S}$ rRNA gene bacterial species in 3 classes and 8 families.

The majority of $16 \mathrm{~S}$ rRNA sequences detected are from bacteria belonging to the Gammaproteobacteria class (Table 1). The Pseudomonas sp. and Aeromonas sp. are species detected in most of the

Table 1. Details of molecular identification of bacteria species in An. stephensi, An. maculipennis specimens and breeding places.

\begin{tabular}{|c|c|c|c|c|c|c|c|c|}
\hline No. & Strain & Nearest species & $\begin{array}{l}\text { Ac. no. of } \\
\text { identified } \\
\text { bacteria }\end{array}$ & $\begin{array}{l}\text { Max } \\
\text { identity }\end{array}$ & $\begin{array}{l}\text { Ac. no. of the } \\
\text { closest species } \\
\text { in gene bank }\end{array}$ & Class & Family & $\begin{array}{l}\text { Product } \\
\text { size(bp) }\end{array}$ \\
\hline 1 & Ast1L & Pantoea agglomerans & & 99 & AY849936.1 & Gammaproteobacteria & Enterobacteriaceae & 1500 \\
\hline 2 & Ast2L & Pantoea stewartii & & 98 & AF373198.1 & Gammaproteobacteria & Enterobacteriaceae & 911 \\
\hline 3 & Lst1L & Bacillus pumilus & & 99 & GQ152134.1 & Bacillales & Bacillaceae & 1507 \\
\hline 4 & Lst2L & $\begin{array}{l}\text { Sphingomonas } \\
\text { paucimobilis }\end{array}$ & & 98 & D16144.1 & Alphaproteobacteria & Sphingomonadaceae & 1447 \\
\hline 5 & Lst3F & $\begin{array}{l}\text { Brevundimonas } \\
\text { aurantiaca }\end{array}$ & & 99 & AJ227787.1 & Alphaproteobacteria & Caulobacteraceae & 1419 \\
\hline 6 & Lst4F & $\begin{array}{l}\text { Brevundimonas } \\
\text { aurantiaca }\end{array}$ & & 99 & AJ227787.1 & Alphaproteobacteria & Caulobacteraceae & 1419 \\
\hline 7 & Lst5F & $\begin{array}{l}\text { Brevundimonas } \\
\text { aurantiaca }\end{array}$ & & 99 & AJ227787.1 & Alphaproteobacteria & Caulobacteraceae & 1419 \\
\hline 8 & Lst6F & Lysinibacillus sphaericus & & 99 & CP000817 & Bacillales & Planococcaceae & 1510 \\
\hline 9 & Lst7F & Rahnella aquatilis & & 98 & U90757.1 & Gammaproteobacteria & Enterobacteriaceae & 1501 \\
\hline 10 & Lma1F & Aeromonas bivalvium & & 99 & DQ504429.1 & Gammaproteobacteria & Aeromonadaceae & 951 \\
\hline 11 & Lma2F & $\begin{array}{l}\text { Pseudomonas } \\
\text { mendocina }\end{array}$ & & 100 & DQ178224.1 & Gammaproteobacteria & Pseudomonadaceae & 1495 \\
\hline 12 & Lma3F & Lysinibacillus sphaericus & & 99 & СР000817.1 & Bacillales & Planococcaceae & 1510 \\
\hline 13 & Lma4F & Aeromonas punctata & & 95 & GQ259885.2 & Gammaproteobacteria & Aeromonadaceae & 1446 \\
\hline 14 & RW1 & Pseudomonas otitidis & & 99 & AY953147.1 & Gammaproteobacteria & Pseudomonadaceae & 1495 \\
\hline 15 & RW2 & Pseudomonas otitidis & & 99 & AY953147 & Gammaproteobacteria & Pseudomonadaceae & 1496 \\
\hline 16 & TW1 & $\begin{array}{l}\text { Acinetobacter } \\
\text { calcoaceticus }\end{array}$ & & 99 & AJ888983.1 & Gammaproteobacteria & Moraxellaceae & 1508 \\
\hline 17 & TW2 & Aeromonas hydrophila & & 99 & GQ184148.1 & Gammaproteobacteria & Aeromonadaceae & 1506 \\
\hline 18 & TW3 & Bacillus pumilus & & 99 & FJ768456.1 & Bacillales & Bacillaceae & 1507 \\
\hline 19 & TW4 & Rahnella aquatilis & & 98 & U90757.1 & Gammaproteobacteria & Enterobacteriaceae & 1500 \\
\hline 20 & TW5 & Rahnella aquatilis & & 98 & U90757.1 & Gammaproteobacteria & Enterobacteriaceae & 1500 \\
\hline
\end{tabular}

Ast (Adult sample of An. stephensi), Lst (Larvae of An. stephensi), Lma (Larvae of An. maculipennis), RW (Rasht Breeding Sites), TW: (Talesh Breeding Sites). L and F are labreared and field-caught specimens, respectively.

doi:10.1371/journal.pone.0028484.t001 
Table 2. Molecular identification of bacteria species based on breeding sites, adults and larvae of mosquitoes.

\begin{tabular}{|c|c|c|c|c|c|c|}
\hline \multicolumn{2}{|l|}{$\begin{array}{l}\text { Source } \\
\text { of sample }\end{array}$} & \multicolumn{4}{|c|}{ Identified bacteria species } & \\
\hline Breeding sites & Talesh & Rahnella aquatilis & Aeromonas hydrophila & Bacillus pumilus & Acinetobacter calcoaceticus & \\
\hline & Rasht & Pseudomonas otitidis & & & & \\
\hline \multirow[t]{2}{*}{ Larvae sample } & An. maculipennis & Pseudomonas mendocina & Aeromonas punctata & Aeromonas bivalvium & Lysinibacillus sphaericus & \\
\hline & An. stephensi & Bacillus pumilus & $\begin{array}{l}\text { Brevundimonas } \\
\text { aurantiaca }\end{array}$ & $\begin{array}{l}\text { Lysinibacillus } \\
\text { sphaericus }\end{array}$ & $\begin{array}{l}\text { Sphingomonas } \\
\text { paucimobilis }\end{array}$ & Rahnella aquatilis \\
\hline Adult sample & An. stephensi & Pantoea agglomerans & Pantoea stewartii & & & \\
\hline
\end{tabular}

specimens analyzed by two biochemical and molecular pathways. These species are found in breeding sites of both An. stephensi and An. maculipennis in South and North-eastern of Iran and in Anopheles larvae and adult specimens (Tables 2 and 3). However, although there is no significance co-relation among the bacterial species and anopheles species or specific breeding site, but for example, Lysinibacillus sphaericus have been detected in both larvae of $A n$. maculipennis and An. stephensi that originated from two different zoogeographical regions of Palearctic and Oriental, or An. stephensi larvae share two bacteria of Bacillus pumilus and Rahnella aquatilis with the Talesh breeding site in north of country (Tables 2 and 3). This result is encouraging because the use of paratransgenesis requires a bacterium that could be introduced to the majority of the mosquito vector populations and could be transferred within breeding sites to different stages of larvae, pupae and adults. Many of the $16 \mathrm{~S}$ rRNA sequences retrieved from our samples are similar to those of gut bacteria found in other mosquitoes. The Aeromonas and Pseudomonas species were isolated from Cx. quinquefasciatus [15] in India, An. gambiae [17] in Africa, An. darlingi in Brazil [18] and field collected An. stephensi larvae [19] in India. Some of our sequences deduced from breeding sites and Anopheles larvae (Lma2, RW1, RW2 strains) are closely related to the Pseudomonas sp. clone H2.26 (AY837753) from adult An. gambiae [17] (Fig. 1).

Other detected bacteria species in the current study, including Pantoea, Bacillus and Acinetobacter (Tables 1, 2, and 3), have been reported recently from different Culicidae mosquitoes. Pantoea sp. was found in Cx. quinquefasciatus [15] in Africa and An. darlingi in Brazil [18]. Fouda et al. concluded that the isolated Bacillus from a laboratory colony of Culex pipiens mosquitoe midguts were essential for high and normal fecundity [20]. Bacillus sp. was also reported from African An. gambiae [17], Cx. quinquefasciatus [15] and $A n$. stephensi larvae in India [19]. Acinetobacter sp. was found in $C x$. quinquefasciatus [15] and field-collected male, female and larvae of An. stephensi [19].

Besides, some other bacteria species, including Acinetobacter bomani, Pseudomonas florsen and Enterobacter sp. from breeding sites, Pseodomonas aerogenosis from adult Anopheles, and Acinetobacter, E. coli, Klebsieila ozenae and Shigella sp. from Anopheles larvae, were identified just by using the biochemical pathway. These species were also identified from some mosquitoes by molecular pathway. Lindh et al. [17] and Rani et al. [19] reported Escherichia sp. from An. arabiensis and field-collected male An. stephensi, respectively.

Terenius et al. [18] reported 56 sequences of $16 \mathrm{~S}$ rRNA gene of 56 bacterial species from six mosquitoes, including five blood-fed and one non blood-fed mosquitoes. They extracted DNA from whole mosquitoes, which could be one of the reasons for detection of a large number of bacteria, whereas some bacteria from cuticle or other unrelated parts of mosquito's body can be reported in spite of their irrelevance to paratransgenic approach. Although Terenius et al. [18] assumed that non blood-fed mosquitoes did not amplify any product, indicating that bacteria on the exoskeleton of the mosquitoes were too few to affect the results; our results do not confirm this whereas most samples in our current study were nonblood-fed. The other reason for large numbers of bacteria in Terenius et al. [18] study, could be using the blood-fed samples because the bacterial load increases after blood meal.

Similarly to our result, Lindh et al. [17] detected bacteria in a low percent of the mosquitoes that had been analyzed using the

Table 3. Molecular identification of bacteria species based on common bacterial species in each source.

\begin{tabular}{|c|c|c|c|c|c|c|c|c|c|c|c|c|c|c|}
\hline \multicolumn{2}{|c|}{ Bacteria species } & $\begin{array}{l}\text { Pan. } \\
\text { agg }\end{array}$ & $\begin{array}{l}\text { Pan. } \\
\text { ste }\end{array}$ & $\begin{array}{l}\text { Bac. } \\
\text { pum }\end{array}$ & $\begin{array}{l}\text { Sph. } \\
\text { pau }\end{array}$ & $\begin{array}{l}\text { Bre. } \\
\text { aur }\end{array}$ & $\begin{array}{l}\text { Lys. } \\
\text { sph }\end{array}$ & $\begin{array}{l}\text { Rah. } \\
\text { aqu }\end{array}$ & $\begin{array}{l}\text { Aer. } \\
\text { biv }\end{array}$ & $\begin{array}{l}\text { Pse. } \\
\text { men }\end{array}$ & $\begin{array}{l}\text { Aer. } \\
\text { pun }\end{array}$ & $\begin{array}{l}\text { Pse. } \\
\text { oti }\end{array}$ & Aci. cal & Aer. hyd \\
\hline \multicolumn{2}{|c|}{ Sources of samples } & 1 & 2 & 3 & 4 & 5 & 6 & 7 & 8 & 9 & 10 & 11 & 12 & 13 \\
\hline \multirow{2}{*}{$\begin{array}{l}\text { Breeding } \\
\text { sites }\end{array}$} & Talesh & & & • & & & & • & & & & & • & • \\
\hline & Rasht & & & & & & & & & & & - & & \\
\hline \multirow{2}{*}{$\begin{array}{l}\text { Larvae } \\
\text { sample }\end{array}$} & An. maculipennis & & & & & & $\cdot$ & & • & • & • & & & \\
\hline & An. stephensi & & & & - & - & - & & & & & & & \\
\hline $\begin{array}{l}\text { Adult } \\
\text { sample }\end{array}$ & An. stephensi & • & - & • & & & & & & & & & & \\
\hline
\end{tabular}

·1(Pantoea agglomerans), 2(Pantoea stewartii), 3(Bacillus pumilus), 4 (Sphingomonas paucimobilis), 5(Brevundimonas aurantiaca), 6(Lysinibacillus sphaericus), 7(Rahnella aquatilis), 8(Aeromonas bivalvium), 9(Pseudomonas mendocina), 10(Aeromonas punctata), 11(Pseudomonas otitidis), 12(Acinetobacter calcoaceticus), 13(Aeromonas hydrophila).

doi:10.1371/journal.pone.0028484.t003 


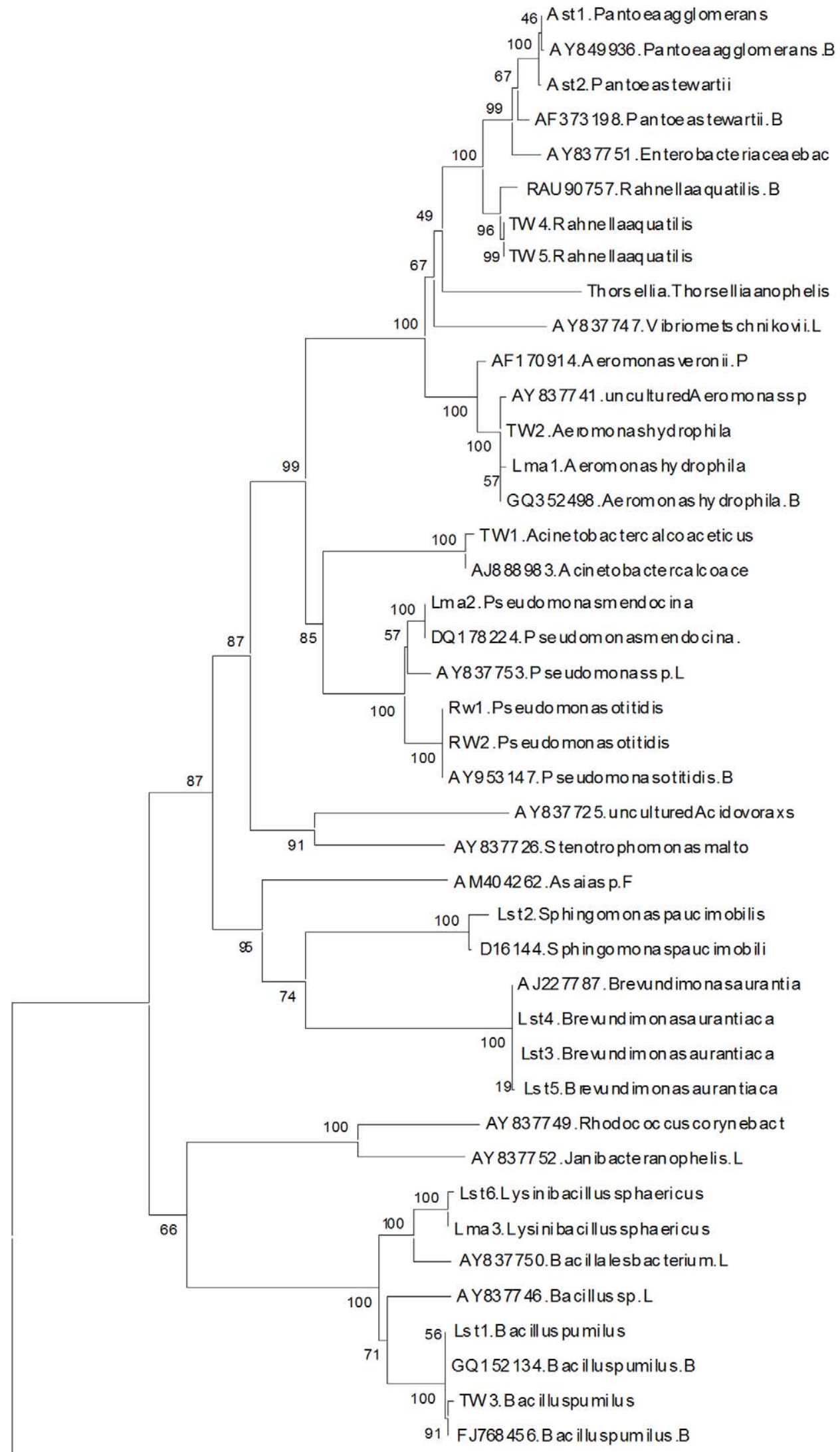

A Y837724. un cultu red My coplas mas 
Figure 1. Phylogenetic dendrogram constructed in Mega4 based on 16S rRNA gene sequences. Bacteria species released in GenBank are appeared with accession number and species of bacteria. Those bacteria detected in current study are Ast (Adult sample of An. stephensi), Lst (Larvae of An. stephensi), Lma (Larvae of An. maculipennis), RW (Rasht breeding sites), TW (Talesh breeding sites). doi:10.1371/journal.pone.0028484.g001

same PCR conditions. Some of the identified bacteria (Pseudomonas, Aeromonas, Bacillus) in breeding sites were also detected in larvae (molecular identification) and adults (biochemical identification) (Pseudomonas), but according to low number of identified samples in adult it should be examined further. Although we had enough adult mosquitoes, from 32 examined blood-fed and non blood-fed adult An. maculipennis we could not find any bacteria whereas in all An. stephensi mosquitoes, the bacteria detection was successful.

In the current study, specimens were identified by biochemical and culture-dependent pathways. Moreover, in spite of using two different pathways, including culture-independent and culture dependent in some recent papers, we did not use culture-independent pathway because by using culture independent pathway (PCR based methods), the identified genera could not be retrieved by the culture-dependent method [17]. One explanation might be the remnants of the midgut cells or human blood interfere in PCR reaction. Another explanation could be the competition of DNAs from different bacteria that led to the successful amplification of ones with the higher abundance [17].

So far, several bacteria have been isolated from anophelines, from both laboratory colonies and wild populations and at least one bacterium, Enterobacter agglomerans, has been identified as an excellent candidate for paratransgenesis [13,21]. Inhibition of malaria parasite development has been shown in Yoshida et al. [22] study where E. coli was fed to An. stephensi.Using a single-chain antibody against Plasmodium berghei ookinete, Pbs21 linked to the lytic peptide Shiva-1, resulted in 95.6\% transmission blockage. Furthermore, in a recent study, the expression of two antiPlasmodium effector molecules (SM1 and phospholipase-A2 (PLA2)) on the surface of $E$. coli, partially inhibited the $P$. berghei development, showed the potential role of this strategy for malaria control programs $[21,23]$.

The data presented from the current study revealed a great diversity of the midgut microbiota in An. stephensi and An. maculipennis and presented potentially new species. This justifies further search and isolation of useful bacteria for paratransgenesis.

All of the bacterial isolates in this study will be further evaluated for their suitability as paratransgenic tools. The first step will be the sustainability study in mosquito midguts after reintroduction and the second step is the assessment of the immune response that induced by the bacteria. The survival of a reintroduced bacterium will depend on the tolerance level to immune response that mounted by the mosquito and putative antagonistic effects of other midgut bacteria. Several studies have shown that Gram-negative midgut bacteria can suppress Plasmodium parasites development $[14,24,25]$, possibly by acting as elicitors of the mosquito immune response that affecting on Plasmodium development [25]. Hence, an ideal bacterium for paratransgenics would be one that elicits a potent immune response that suppresses other bacteria and Plasmodium parasites but does not affect on own survival. Therefore, genetic modification of this bacterium by introducing a gene that expresses an antiparasitic molecule, could achieve the clearance of Plasmodium parasites from the mosquito midgut. From this point of view, it is promising that several isolates detected in the current study are Gram-negative, proteobacteria, and these are suitable elements for genetic modification [17].

Further, recently a great deal of attention has been addressed to bacteria of the genus Asaia, which have been proposed as the best potential candidates for malaria control $[26,27,28]$. In the original screening, we could not identify Asaia that this is most likely due to the fact that it grows in very peculiar conditions [26]. Also, bacterial identification by molecular analysis can be strongly biased by the kind of primers that are used in ribosomal gene amplification. However, by using Asaia specific primers, we could not detect its presence in any of the analyzed samples.

On the other hand, Cirimotich et al [29]identified an Enterobacter bacterium isolated from wild mosquito populations in Zambia that renders the mosquito resistant to infection with the human malaria parasite Plasmodium falciparum by interfering with parasite development before invasion of the midgut epithelium. These means that despite the use of identified bacteria in paratransgenic strategy, it is also possible to raise the anti-Plasmodium mechanism through mediating a mosquito-independent interaction of small populations of replicating bacteria with the malaria parasite, which is reported to be largely caused by bacterial generation of reactive oxygen species.

Accordingly, the detection of 13 sequences of 16S rRNA gene bacterial species (categorized in 8 families) in two main malaria vector species, An. maculipennis from Palearctic region and $A n$. stephensi from western extend of Oriental region in current study, strongly encourage further investigations, to verify the potential role of the detected bacteria in malaria control in Iran and neighboring countries.

\section{Materials and Methods}

\section{Ethics Statement}

All projects, prior to the approval by Pasteur institute of Iran (PII) and Ministry Of Health (MOH), should had been reviewed and cleared by the ethical committee of PII and hence, in mosquito collection from private residences, all residents provided their oral informed consent to have their residences used in the study by coordination through "Local Manager of Malaria Control Program" of Public Health Center in the study areas. Briefly, the PI for the project, N. Dinparast Djadid (NDD), presented the different sections of project to the local staff, especially the field collection section. One to two weeks prior to field collection, the "Local Manager of Malaria Control Program" of Public Health Center, had a visit from the study areas and in a meeting with residents, asked their permission for mosquito collection in the defined date and time. As it is a routine procedure for other activities of malaria control program in the region, the residents accepted to cooperate in the project, which followed by the presence of the research team in the agreed date and time within the study areas and performing the mosquito collection. This has been documented in "Weekly Activity Report Book" of the Malaria Control Program in the study areas, signed by the PI (NDD), the manager of malaria control program and a representative from the study areas.

\section{Collection of mosquito species and isolation of bacterial flora}

Adult and larvae mosquito specimens of An. stephensi and An. maculipennis were collected by total catch and hand catch in human and animal shelters and also their breeding sites from provinces of Sistan and Baluchestan in South West of Iran and Guilan in northern Iran (Fig. 2). Specimens species were identified by using the morphological key of Iranian Anophelines [30] to distinguish 
An. stephensi and An. maculipennis adults from other Anopheles species. The details of the origin and the number of specimens that were sequenced and the detected bacteria have been presented in Table 1.

Living mosquitoes were anesthetized by putting them on ice and dissection was done under sterile conditions after surface sterilization with $70 \%$ ethanol. The midgut content was suspended in $50 \mu \mathrm{l}$ of sterile saline $(0.9 \% \mathrm{NaCl})$; A $25 \mu \mathrm{L}$ aliquot of this content was plated onto blood agar base (Merck, Germany) with $7 \%$ (v/v) human blood, and $25 \mu \mathrm{L}$ aliquot of the content was plated onto MacConkey agar base (Merck, Germany) followed by incubation at $37^{\circ} \mathrm{C}$ for $18-24$ hours. The sterility of all reagents was checked during the entire procedure. The morphology of the Gram-positive bacteria was examined by Gram staining and light microscopy. IMVic, oxidase and different types of supplemental analysis were used for classical phenotyping, depending on the bacterial genus.

Water of the breeding sites were collected in $50 \mathrm{ml}$ sterile falcon tubes and transferred to local laboratories for further process. On arrival, the waters centrifuged in 10,000 rpm for 3 minutes and the pellet from each water was plated on blood agar and MacConkey mediums, followed by biochemical and molecular identification of their bacteria, as carried out for the detection of microbiota of the mosquitoes' midgut.

\section{Genomic DNA extraction, amplification, cloning and sequencing of $16 \mathrm{~S}$ rRNA genes}

The optimum growth of bacteria was gained in LB by shaking at $160 \mathrm{rpm}$ at $37^{\circ} \mathrm{C}$ and spectrophotometric reading. DNA was extracted by using the phenol- chloroform extraction protocol for Gram-negative and -positive bacteria according to the adapted protocols in Microbiology Department, Pasteur Institute of Iran.
The $1.5 \mathrm{~kb}$ of the $16 \mathrm{~s}$ rRNA gene was amplified by using $16 \mathrm{~s}$ forward (5'-AGT TTG ATG CTG GCT CAG-3') and $16 \mathrm{~s}$ reverse (5'-GCT ACC TTG TTA CGA CTT C-3') primers that were designed by Gene Runner,Version 3.05. All PCR reactions were performed in a total volume of $25 \mu \mathrm{l}$. The reaction mixture contained $100 \mathrm{ng}$ of each of the specific primers, 0.2 unit of Taq polymerase, $0.1 \mathrm{mM}$ each of dNTPs, $0.001 \%$ spermidin, $2.5 \mu \mathrm{l}$ of $10 \times$ reaction buffer and $2 \mathrm{mM} \mathrm{MgCl} 2$. The amplification profile was as follows: denaturation at $95^{\circ} \mathrm{C}$ for one minute, followed by 35 cycles of annealing at $54^{\circ} \mathrm{C}$ for one minute and extension at $72^{\circ} \mathrm{C}$ for one minute with 10 minute extra extension time in the last cycle.

Specific forward and reverse primers were designed based on the 16 s rRNA gene of Asaia bacteria Gene Runner, Version 3.05. Asafor (5'-GGG CGT AGG CGG TTT ACA C-3') and Asarev (5'-AGC GTG AGT AAT GAG GCA GGT T-3') [26] were used to amplify a $180 \mathrm{bp}$ fragment. The expected size of PCR products were confirmed by electrophoresis on a $1 \%$ agarose gel that was stained with ethidium bromide and the bands were visualized by UV transillumination. Amplified fragments were purified by CoreOne ${ }^{\mathrm{TM}}$ Gel Elution Kit (Core Bio System Co. Ltd., Seoul, Korea) and PGR products with the expected size were cloned into pDrive TA cloning vectors (QIAGEN). The inserted gene in the plasmids was subjected to sequencing by Millegene Company (Labege, France), using M13 primers [(M13 (-21) and M13R (-29)].

\section{Data analysis and phylogenetic tree}

The sequencing signals of the specimens were double-checked and annotated, followed by comparison with GenBank data. For data analysis, alignment and construction of phylogenetic tree, a series of softwares, including DNASTAR, Lasergene (Version 7.1), Chromas (Version 2.31), Gene Runner (Version 3.05), ClustalX

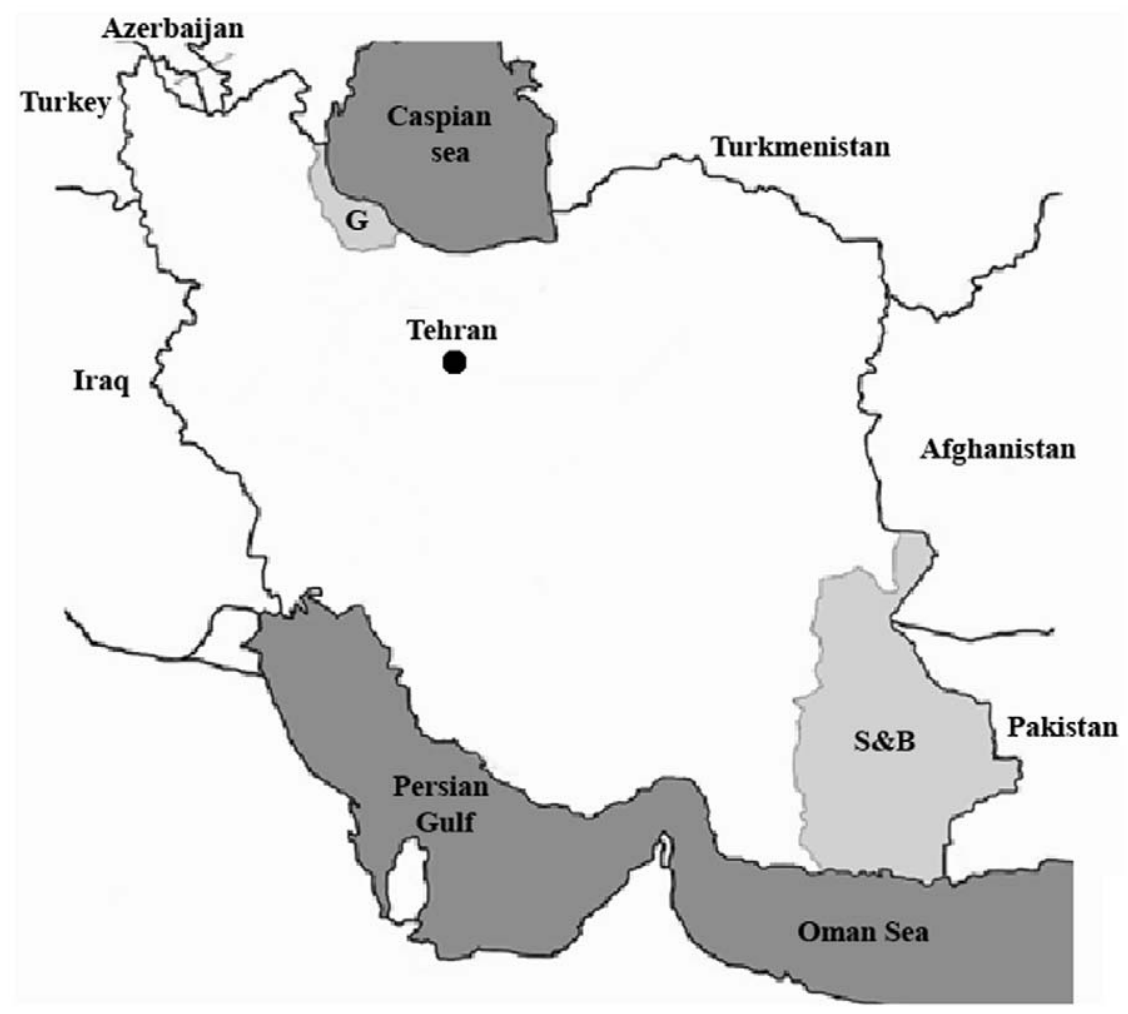

Figure 2. Map of study area, including Guilan (G), Sistan and Baluchestan (S\&B) provinces. doi:10.1371/journal.pone.0028484.g002 
(Version 1.83), ClustalW (1994), Blast (http://www.ncbi.nlm.nih. gov/BLAST/) and other programs that were available in NCBI site and Malaria and Vector Research Group (MVRG), were used.

To determine the phylogenetic relatedness of the strains, the 16S rRNA gene sequence of the mosquito midgut contents were subjected to analysis by using Molecular Evolutionary Genetic Analysis (MEGA4, 2007) software.

\section{Acknowledgments}

We acknowledge gratefully Dr. Ahmad Raeisi, the Manager of National Malaria Control Program, and the staff of the Amol Research and Production Branch of PII, for their assistance and coordination in field

\section{References}

1. Ross R (1897) On some Peculiar Pigmented Cells Found in Two Mosquitos Fed on Malarial Blood. Br Med J 2: 1786-1788.

2. Ross R (1897) Observations on a Condition Necessary to the Transformation of the Malaria Crescent. Br Med J 1: 251-255.

3. Ramirez JL, Garver LS, Dimopoulos G (2009) Challenges and approaches for mosquito targeted malaria control. Curr Mol Med 9: 116-130.

4. Beard CB, Cordon-Rosales C, Durvasula RV (2002) Bacterial symbionts of the triatominae and their potential use in control of Chagas disease transmission. Annu Rev Entomol 47: 123-141.

5. Durvasula RV, Gumbs A, Panackal A, Kruglov O, Aksoy S, et al. (1997) Prevention of insect-borne disease: an approach using transgenic symbiotic bacteria. Proc Natl Acad Sci U S A 94: 3274-3278.

6. Chao J, Wistreich GA (1959) Microbial isolations from the midgut of Culex tarsalis Coquillett. J Insect Pathol 1: 311-318.

7. Chao J, Wistreich GA (1960) Microorganisms from the midgut of larval and adult Culex quinquefasciatus Say. J Insect Pathol 2: 220-224.

8. Ferguson MJ, Micks DW (1961) Microorganisms associated with mosquitoes: bacteria isolated from adult Culex fratigans Wiedemann. J Insect Pathol 3: $112-119$.

9. Jadin J, Vincke IH, Dunjic A, Delville JP, Wery M, et al. (1966) [Role of Pseudomonas in the sporogenesis of the hematozoon of malaria in the mosquito]. Bull Soc Pathol Exot Filiales 59: 514-525.

10. Seitz HM, Maier WA, Rottok M, Becker-Feldmann H (1987) Concomitant infections of Anopheles stephensi with Plasmodium berghei and Serratia marcescens: additive detrimental effects. Zentralbl Bakteriol Mikrobiol Hyg A 266: 155-166.

11. Demaio J, Pumpuni CB, Kent M, Beier JC (1996) The midgut bacterial flora of wild Aedes triseriatus, Culex pipiens, and Psorophora columbiae mosquitoes. Am J Trop Med Hyg 54: 219-223.

12. Vasanthi V, Hoti SL (1992) Microbial flora in gut of Culex quinquefasciatus breeding in cess pits. Southeast Asian J Trop Med Public Health 23: 312-317.

13. Straif SC, Mbogo CN, Toure AM, Walker ED, Kaufman M, et al. (1998) Midgut bacteria in Anopheles gambiae and An. funestus (Diptera: Culicidae) from Kenva and Mali. J Med Entomol 35: 222-226.

14. Gonzalez-Ceron L, Santillan F, Rodriguez MH, Mendez D, Hernandez-Avila JE (2003) Bacteria in midguts of field-collected Anopheles albimanus block Plasmodium vivax sporogonic development. J Med Entomol 40: 371-374.

15. Pidiyar V, Kaznowski A, Narayan NB, Patole M, Shouche YS (2002) Aeromonas culicicola sp. nov., from the midgut of Culex quinquefasciatus. Int J Syst Evol Microbiol 52: 1723-1728.

16. Pidivar VJ, Jangid K, Patole MS, Shouche YS (2004) Studies on cultured and uncultured microbiota of wild culex quinquefasciatus mosquito midgut based on 16 s ribosomal RNA gene analysis. Am J Trop Med Hyg 70: 597-603. sampling. We thank Dr. A. Abouei, Dr. S. Gholizadeh and also colleagues in the Department of Bacteriology, PII, for their technical assistance.

\section{Author Contributions}

Conceived and designed the experiments: NDD GF. Performed the experiments: HJ AR. Analyzed the data: HJ AR. Contributed reagents/ materials/analysis tools: NDD HJ AR. Wrote the paper: HJ. Supervised the field and laboratory research works and finalized the manuscript: NDD GF. Performed most of the practical in laboratory and drafted the manuscript: HJ. Performed some of the practical, shared the bioinformatics analysis and reviewed the manuscript: AR. Jointly designed the project with NDD, partly advised in practical sections and reviewed the manuscript: GF. Partly cooperated in practical: IR. Advised on practical and reviewed the manuscript: SZ.

17. Lindh JM, Terenius O, Faye I (2005) 16S rRNA gene-based identification of midgut bacteria from field-caught Anopheles gambiae sensu lato and A. funestus mosquitoes reveals new species related to known insect symbionts. Appl Environ Microbiol 71: 7217-7223.

18. Terenius O, de Oliveira CD, Pinheiro WD, Tadei WP, James AA, et al. (2008) $16 \mathrm{~S}$ rRNA gene sequences from bacteria associated with adult Anopheles darlingi (Diptera: Culicidae) mosquitoes. J Med Entomol 45: 172-175.

19. Rani A, Sharma A, Rajagopal R, Adak T, Bhatnagar RK (2009) Bacterial diversity analysis of larvae and adult midgut microflora using culture-dependent and culture-independent methods in lab-reared and field-collected Anopheles stephensi-an Asian malarial vector. BMC Microbiol 9: 96.

20. Fouda MA, Hassan MI, Al-Daly AG, Hammad KM (2001) Effect of midgut bacteria of Culex pipiens L. on digestion and reproduction. J Egypt Soc Parasitol 31: 767-780.

21. Riehle MA, Moreira CK, Lampe D, Lauzon C, Jacobs-Lorena M (2007) Using bacteria to express and display anti-Plasmodium molecules in the mosquito midgut. Int J Parasitol 37: 595-603.

22. Yoshida S, Ioka D, Matsuoka H, Endo H, Ishii A (2001) Bacteria expressing single-chain immunotoxin inhibit malaria parasite development in mosquitoes. Mol Biochem Parasitol 113: 89-96.

23. Ramirez JL, Garver LS, Dimopoulos G (2009) Challenges and approaches for mosquito targeted malaria control. Curr Mol Med 9: 116-130.

24. Pumpuni CB, Beier MS, Nataro JP, Guers LD, Davis JR (1993) Plasmodium falciparum: inhibition of sporogonic development in Anopheles stephensi by gram-negative bacteria. Exp Parasitol 77: 195-199.

25. Pumpuni CB, Demaio J, Kent M, Davis JR, Beier JC (1996) Bacterial population dynamics in three anopheline species: the impact on Plasmodium sporogonic development. Am J Trop Med Hyg 54: 214-218.

26. Favia G, Ricci I, Damiani C, Raddadi N, Crotti E, et al. (2007) Bacteria of the genus Asaia stably associate with Anopheles stephensi, an Asian malarial mosquito vector. Proc Natl Acad Sci U S A 104: 9047-9051.

27. Damiani C, Ricci I, Crotti E, Rossi P, Rizzi A, et al. (2010) Mosquito-Bacteria Symbiosis: The Case of Anopheles gambiae and Asaia. Microb Ecol. pp $644-654$.

28. Damiani C, Ricci I, Crotti E, Rossi P, Rizzi A, et al. (2008) Paternal transmission of symbiotic bacteria in malaria vectors. Curr Biol 18: R1087-1088.

29. Cirimotich CM, Dong YM, Clayton AM, Sandiford SL, Souza-Neto JA, et al. (2011) Natural Microbe-Mediated Refractoriness to Plasmodium Infection in Anopheles gambiae. Science 332: 855-858.

30. Shahgudian ER (1960) A key to the anophelines of Iran. Acta Med Iran 3: $38-48$. 